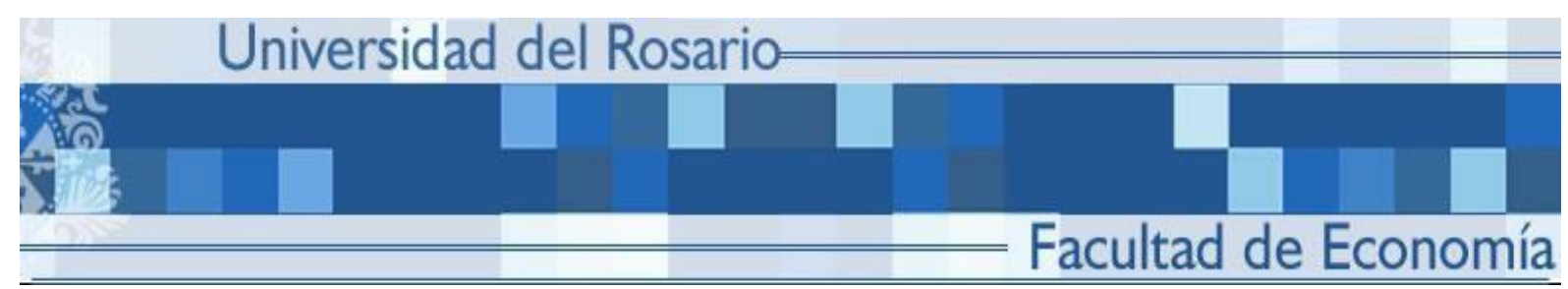

Civil Conflict and Voting Behavior: Evidence from Colombia

Jorge Gallego

SERIE DOCUMENTOS DE TRABAJO

No. 194

Septiembre de 2016 


\title{
Civil Conflict and Voting Behavior: Evidence from Colombia*
}

\author{
Jorge Gallego ${ }^{\dagger}$
}

September 24, 2016

\begin{abstract}
What are the effects of war on political behavior? Colombia is an interesting case in which conflict and elections coexist, and illegal armed groups intentionally affect electoral outcomes. Nonetheless, groups use different strategies to alter these results. This paper argues that differential effects of violence on electoral outcomes are the result of deliberate strategies followed by illegal groups, which in turn, are a consequence of military conditions that differ between them. Using panel data from Senate elections from 1994 to 2006 and an instrumental variable approach to address potential endogeneity concerns, this paper shows that guerrilla violence decreases turnout, while paramilitary violence has no effect on participation, but reduces electoral competition and benefits non-traditional third parties. FARC violence is significantly higher during election years, while paramilitary violence is lower. This is consistent with the hypothesis that the guerrilla's strategy is to sabotage elections, while paramilitaries establish alliances with certain candidates.
\end{abstract}

${ }^{*}$ I would like to thank Mario Chacon, Oeindrila Dube, John Ferejohn, Thomas Flores, Jennifer Hill, Andrew Little, Rebecca Morton, Ben Pasquale, Adam Przeworski, Pablo Querubin, Andres Rosas, Jorge Restrepo, Daniel Rico, Alexandra Scacco, Alastair Smith, Andres Vargas, Juan Vargas, and Leonard Wantchekon for their helpful comments. I am also specially grateful to the Conflict Analysis Resource Center (CERAC) for providing valuable data, information, and support at different stages of this project. Naturally, all errors are my responsibility.

${ }^{\dagger}$ Facultad de Economía, Universidad del Rosario. jorge.gallego@urosario.edu.co 


\section{Introduction}

In the context of civil conflict, in which several illegal armed groups are fighting with each other or against the state, why do they use divergent strategies to alter voting behavior and affect electoral outcomes? In the case of Colombia, why is it that FARC's strategy is to sabotage elections and suppress turnout, while the paramilitaries establish alliances with candidates and encourage (or coerce) certain citizens to vote for them? The goal of this paper is to show that indeed different armed non-state groups use a wide range of strategies to alter voters' behavior and that the choice of such strategies is not random, but dependent on military and structural characteristics of these groups.

The basic mechanism proposed in this paper is that military conditions and the strategic interaction between armed groups, elites, and the candidates that represent them, determine the types of instruments used by these groups to alter electoral results. Furthermore, when an illegal armed group establishes territorial control over a populated region, cooperation with the interest groups that coexist in such places becomes feasible and self-enforcing. In the medium and the long term, strategic alliances between armed groups or mafias, candidates and economic elites occur as a result of "tacit" agreements, given that these relationships are not enforceable through contracts. Nonetheless, repeated interaction between the agents, which occurs when armed groups achieve territorial stability or control, offers incentives for compliance. Therefore, when territorial stability is achieved (as in the case of mafias in the U.S. or paramilitaries in Colombia), violent groups tend to form alliances with candidates and coerce voters to support them.

In contrast, when mobility is a basic warfare strategy of an armed group, it is much harder to achieve territorial control and to establish strategic alliances with dominant elites in the regions of influence. Guerrilla groups, in the context of irregular civil wars (Kalyvas (2006); Kalyvas and Balcells (2010)), appeal to guerrilla warfare, in which mobility, surprise attacks, ambushes and raids are the main strategies employed. Under such conditions, it is more difficult to establish strong ties with politicians and regional elites. This situation is the case with groups, such as FARC in Colombia and Shining Path in Peru. This argument

does not pretend to say that these types of groups do not achieve territorial control. But, if such control is established in rural, peripheral and unpopulated regions or within jungles or mountains, not surprisingly, alliances are harder to implement.

In sum, the basic claim defended in this paper is that ideology (being pro or anti-state) is not the only determinant of the strategies employed by armed groups to alter voting behavior. Military strategies and the nature of war also matter. Territorial stability and the possibility of offering certain services to the elites, such as security, are crucial characteristics that enable 
armed groups to support particular candidates instead of boycotting the elections.

Within this theoretical framework, what are the effects of civil conflict on voting behavior? In order to address potential endogeneity concerns in the relationship between violence and political outcome, an instrumental variable approach is followed in this paper, analyzing Senate elections from 1994 to 2006 in Colombia. This paper exploits the fact that, after 1998, FARC attacks were more common around the region in which a failed peace process took place. Additionally, in the case of paramilitary violence, this paper exploits the fact that these groups had special interests on lands suitable for the cultivation of oil palm trees.

My estimations reveal that an additional unit in the rate of FARC attacks (per 100,000 habitants) decreases voter turnout by almost $4 \%$, while paramilitary violence has no significant effect. These results are robust to different measures of violence. In addition, it is realized that, after 1998, electoral competition, measured by the vote share of the winning candidate, is lower in municipalities attacked by paramilitaries. Also, after 1998, traditional parties have exhibited a decrease in their senate vote shares, while third parties (small, newly created, nontraditional parties) have increased their shares. This suggests that politicians that established alliances with paramilitaries utilized these new parties as the main channels for acquiring votes. Supplementing this, FARC violence is significantly higher during election years, while paramilitary violence is lower. This is consistent with the hypothesis that the guerrilla's strategy is to sabotage the elections, while the paramilitaries establish alliances with certain candidates.

Overall, these results have important implications in the actual context of Colombia's conflict. First, if some of the successors of paramilitary groups, in the form of criminal gangs, still control entire territories of the country, it would no be surprising if they employ illicit strategies in order to coerce people to vote against FARC and government agreements. Second, demobilization of FARC and their commitment to the peace process should reflect increased turnout in the regions where they exerted some influence, starting with the plebiscite.

This paper is hereby divided into 6 sections, including this introduction. The relation of the paper to the existing literature is discussed in section two. In the third section, background on Colombia's civil conflict is presented. This section also discusses the empirical strategy proposed to understand the causal effects of civil conflict on voter behavior. Section four then describes the data analyzed throughout the paper and provides relevant descriptive statistics. Finally, in section five the main results are presented, demonstrating that FARC attacks decrease turnout, while paramilitary attacks have no impact on turnout, yet have a differential impact on electoral competition and parties' vote shares after 1998. This section also provides evidence in favor of the proposed mechanism. The paper concludes with the discussion in section six. 


\section{Literature}

The broad connection between elections and violence has intrigued several authors and inspired interesting studies (Snyder (2000), Varshney (2002), Brass (2003), Dunning (2011), Bekoe (2012) or Hefner-Burton and Jablonski (2014)). This paper represents a contribution to at least four groups of studies that analyze this relationship. First, it is related to the literature pertaining to the political and electoral legacies of civil war. Authors like Bellows and Miguel (2009) and Blattman (2009) analyze the causal effects of civil conflict on political behavior, both with optimistic results. Analyzing the Sierra Leone civil war, Bellows and Miguel find that voter registration in postwar elections is higher in areas that experienced increased levels of violence. Blattman finds that forced recruitment leads to an increase in the likelihood of voting. The results presented in this paper are less optimistic, as people have lower levels of political participation in FARC territories.

The paper also speaks to the literature on the effects of terrorism on electoral outcomes. Montalvo (2010), for instance, using al Qaeda's terrorist attacks in Madrid, shows how these events have the capacity to affect how people vote. Within the context of the Israeli-Palestine conflict, authors like Getmansky and Zeitzoff (2014) and Berrebi and Klor (2008), show that terrorism causes an increase in the relative support for right-wing parties. In a similar vein, Kibris (2011) shows that PKK attacks in Turkey make voters punish the incumbent and support less concessionist parties. In this paper a strong connection between paramilitary attacks and support for right-wing parties is also found, but for different reasons that will be discussed below.

The third group of studies closely related to this paper corresponds to the literature on the strategic use of violence to obtain votes. Wilkinson (2006) offers an interesting account of the relationship between conflict and democracy, showing how ethnic riots are employed

as instruments for encouraging people to vote. Norton (2007) shows how Hezbollah has influenced Lebanese domestic politics, which demonstrates that this group's mix of violence and politics has been electorally successful. In the context of Nigeria's 2007 presidential election, Collier and Vicente (2014) find that intimidation and violence, mainly used by weak parties and challengers, are effective in reducing voter turnout. These results are consistent with the finding of this paper that attacks affect variables such as turnout and competition, and that violence has been used strategically to alter elections.

Finally, this paper has a strong connection to the burgeoning literature on the political economy of paramilitaries and insurgencies in Colombia. Several studies have shown how these groups established alliances with certain candidates and forced voters to support them (see for example Acemoglu et al. (2013), Hoskin and Garcia (2003), Garcia (2008) Romero 
(2007), Lopez (2007), or Lopez (2010)). Dube and Naidu (2015) study the connection between U.S. aid, paramilitary violence and electoral outcomes. Steele (2011) claims that displacement perpetrated by paramilitaries in the city of Apartado was strategic and ideologically oriented. Even though these studies provide insight on the connection between violence and elections in Colombia, guerrilla strategies are usually absent in these accounts, being Weintraub et al. (2015) a notable exception.

\section{Empirical Strategy}

To uncover the effect of conflict on voting behavior, this paper analyzes Colombian Senate elections $^{1}$ at the municipality level, for election-years 1994, 1998, 2002, and 2006. Given that these elections take place in March and that, in contrast, yearly measures of violence are used, the main specifications use lagged variables. Thus, for example, it is better to use the 1997 rate of FARC attacks to describe what happened in 1998, because otherwise post-electoral measures would be used. This way, it is also possible to mitigate, to some extent, potential endogeneity existing between political outcomes and violence. ${ }^{2}$

The basic specification estimated in this paper calculates, through a linear regression, the effect of FARC, paramilitary, and State attacks on voter turnout, controlling for municipality and election-year fixed effects, and time-varying municipality level controls. Year effects control for municipality-invariant characteristics that are common for a given year and that might be correlated with civil conflict. For instance, if the cancelation of the Caguan peace process in 2001 had a national-level impact on turnout common to all municipalities, this effect will be captured by the year dummies. Municipality fixed effects control for time-invariant characteristics of each municipality, such as climatic and geographic conditions, which tend to be correlated with war. Therefore, we estimate:

$$
\text { turnout }_{i t}=\alpha+\psi_{i}+\gamma_{t}+\operatorname{Farc}_{i t-1} \beta_{1}+\operatorname{Paras}_{i t-1} \beta_{2}+\mathbf{X}_{i t} \phi+\varepsilon_{i t}
$$

where the dependent variable turnout $_{i t}$ is the percentage of eligible voters who cast a ballot in municipality $i$ during election year $t ; \psi_{i}$ are municipality fixed effects; $\gamma_{t}$ are election-year fixed effects; $\mathbf{X}_{i t}$ is a vector of time-varying municipality level controls, which include State attacks, as well as time-invariant measures of the natural log of population, population density, coca cultivation, and education, ${ }^{3}$ interacted with year dummies. ${ }^{4}$ Finally, the main independent variables are Farc $_{i t-1}$ and Paras $_{i t-1}$, which in the basic models represent the rate of FARC and paramilitary attacks per 100,000 habitants, in municipality $i$ the year before the election at $t$. In other specifications, whose reports are reported on the online appendix and in order 
to test the robustness of the results, these variables will be the average rate of attacks for the three years that precede each election, or a dummy variable indicating if a municipality had any form of attack the year before the election.

From (1), it is clear that the coefficients $\beta_{1}$ and $\beta_{2}$ capture the relationship between voter turnout and FARC and paramilitary attacks, respectively. According to the mechanism proposed in this paper, we expect $\beta_{1}<0$, so that municipalities with higher rates of FARC attacks tend to have lower levels of participation. The sign of $\beta_{2}$ is not straightforward, however. At first glance, intuition would suggest $\beta_{2}>0$, implying that turnout is higher in regions attacked by paramilitaries. But, mobilization of voters is not the only strategy available for the purpose of winning an election. Paramilitaries could encourage those voters who support their candidate, but suppress voters who oppose. In the end, one strategy would cancel the other one, making the aggregate effect indeterminate. Moreover, if paramilitary violence suppresses political competition, mobilization strategies by candidates that oppose to the paramilitaries becomes difficult or unfeasible. ${ }^{5}$

Even though equation (1) includes lagged measures of FARC and paramilitary attacks, it is a concern that these groups could anticipate the level of voter turnout in certain municipalities and, attack them, accordingly. For instance, if FARC's objective is to sabotage elections, they might attack municipalities which they expect will have a high voter turnout. Also, paramilitaries could become active in regions in which low turnout rates are expected, in order to encourage support for their candidates. These forms of reverse causality would lead to endogeneity, biasing the estimations based on (1).

An instrumental variables strategy is used to address this potential endogeneity problem. Given that there are two potentially endogenous regressors, FARC and paramilitary attacks, at least two excluded instruments are needed. Each instrument must be correlated with the respective endogenous regressor, but uncorrelated with the error term. Additionally, given the fixed effects specification followed throughout the paper, time-varying instruments are needed. In the case of the rate of FARC attacks, distance to Caguan will be used in interaction with a post 1998 dummy variable. The discussion given in the previous section justifies this instrument. The post 1998 dummy equals one for election-years 2002 and 2006, after the Caguan peace process was aborted and Plan Colombia was launched. Therefore, and as a consequence of the strengthening of the State forces, during these years FARC attempted to retain the control of municipalities close to Caguan. In this region, the guerrilla was able to develop a fully integrated chain of coca cultivation and cocaine production (Rico, 2010). Therefore, it is expected that, after 1998, as distance to Caguan increases, the rate of FARC attacks decreases, as well. Supplementing this, it is hard to think that this instrument might affect voter turnout through a different channel. Why would citizens further away from the 
demilitarized zone vote more (or less) after 1998, if it is not because of the incidence of FARC attacks?

In the case of paramilitary attacks, we exploit the fact that after the 1998 expansion, these groups became involved in the cultivation of oil palm trees, which grow under very specific geographic and climatic conditions. In particular, and according to Mingorance et al. (2004), this tree grows in lands below 500 meters above the sea level, and with average temperatures within 22 and 32 degrees Celsius. Given these characteristics, a dummy variable is constructed, indicating if a municipality satisfies the conditions for cultivation of oil palm trees. This indicator variable is interacted with the post 1998 dummy, because it is expected that, in 2002 and 2006, years in which the paramilitaries had already consolidated their expansion and demobilized, attacks in these municipalities should have decreased. In particular, attacks in 1998 are expected to be much higher in these municipalities than later, because in this year the AUC were consolidating the control of these regions. Therefore, this study expects that after 1998, municipalities suitable for the cultivation of oil palm trees have a lower rate of paramilitary attacks, so that the instrument is correlated with the endogenous regressor. Also, it is reasonable to believe that this interaction is uncorrelated with any other factor that might affect voter turnout, satisfying the exclusion restriction. In this context, the first stage equations estimated are given by:

$$
\begin{aligned}
& \text { Farc }_{i t-1}=\psi_{i}+\gamma_{t}+\left(\text { ldistcaguan }_{i} \times{\text { post } \left.1998_{t}\right)}\right) \delta_{1}+ \\
& \left(\text { palm }_{i} \times \text { post } 1998_{t}\right) \delta_{2}+\mathbf{X}_{i t} \phi+\omega_{i t} \\
& \text { Paras }_{i t-1}=\psi_{i}+\gamma_{t}+\left(\text { palm }_{i} \times \text { post } 1998_{t}\right) \delta_{3}+ \\
& \left(\text { ldistcaguan }_{i} \times \operatorname{post}_{1998_{t}}\right) \delta_{4}+\mathbf{X}_{i t} \phi+\omega_{i t}
\end{aligned}
$$

where Farc $_{i t-1}$ and Paras $_{i t-1}$ once more represent the rate of attacks per 100,000 inhabitants of FARC and paramilitaries, respectively. Here, palm $m_{i}$ is a dummy variable that equals 1 if the municipality's altitude is below 500 meters and if its average temperature is within the 22 and 32 degrees Celsius range; Also, ldistcaguan $i$ is the natural log of the distance,${ }^{6}$ measured in kilometers, between municipality $i$ and San Vicente del Caguan, the most representative municipality of the demilitarized zone.

The second stage is given by:

$$
\text { turnout }_{i t}=\psi_{i}+\gamma_{t}+\widehat{\operatorname{Far}}_{i t-1} \beta_{1}+\widehat{\operatorname{Paras}}_{i t-1} \beta_{2}+\mathbf{X}_{i t} \eta+\varepsilon_{i t}
$$

where $\widehat{F a r c}_{i t-1}$ and $\widehat{\operatorname{Paras}}_{i t-1}$ are the predicted values that result from the first stage. Finally, standard errors of all specifications are fully robust as they are clustered at the municipality level to allow for arbitrary serial correlation at this level. 


\section{Data}

The main conflict-related data set used in this analysis comes from the Conflict Analysis Resource Center (CERAC). Based on event-counting, this data set reports actions (attacks, bombings, murders, etc.) committed by the actors involved in the Colombian civil conflict (State forces, paramilitaries, and guerrilla groups), as well as clashes between them, at the municipality level (for a total of 1077 municipalities) and from 1988 to 2009 (Restrepo et al. (2004)). The National Registry provide the basic electoral data; Geographical controls for Colombian municipalities are provided by the Center for Study of Economic Development (CEDE) at Universidad de los Andes. Summary statistics are reported in the Online Appendix.

\section{Results}

\subsection{FARC and Paramilitary attacks and Voter Turnout}

In this section, the main results of the effects of civil conflict on voter turnout are presented. Table 1 presents OLS estimates of equation (1). In the complete inventory of specifications, municipality fixed effects and time effects (with year 1994 as the baseline) are included and standard errors are clustered at the municipality level. Columns 1-4 show that the rate of FARC attacks has a negative and significant effect on voter turnout. Columns 1 and 2 do not include time-varying controls at the municipality level, although column 2 indicates that this result is robust to the inclusion of lagged rates of attacks (i.e. rates two years before each election). In columns 3 and 4 , the interaction of year dummies with time-invariant measures of population, population density, coca cultivation and education is included. The same result holds: municipalities with a higher rate of attacks per 100,000 inhabitants tend to have a lower level of turnout.

The coefficient associated with column 1, the simplest specification, shows that a unit increase in the rate of attacks per 100,000 inhabitants reduces turnout by about 0.157 percentage points. Given that for municipalities with a non-zero rate of attacks the average rate is 7.01, turnout is about 1 percentage point lower for an average municipality attacked by FARC when compared to a municipality not attacked. Although these numbers might seem

small, endogeneity might be reducing the real effects if FARC attacks municipalities in which a high turnout rate is expected.

In contrast, the coefficient associated with the rate of paramilitary attacks is insignificant in all the specifications. This result suggests that paramilitary violence has a different effect on turnout, consistent with the idea that the strategies employed by both illegal groups to alter 
electoral results differ. If it is accepted that paramilitaries make alliances with politicians and sponsor certain candidates, it might seem surprising that the effect is not significant and not positive. Nonetheless, this result is still consistent, because it is not necessary to increase turnout in order to make a candidate win. It might be sufficient to suppress opposers' turnout and to encourage supporters of the sponsored candidate. Naturally, if paramilitary intervention is not having an evident effect on turnout, it is desirable to determine if any other variable is being influenced by the violence of these groups. ${ }^{7}$

Table A.3 in the Online Appendix shows that these results are robust to alternative measures of conflict. In alternative specifications conflict is measured using the average rates of attacks by each group during the three immediate years that precede an election, a dummy variable indicating if a municipality had one or more attacks in a given year, or a measure of clashes between legal and illegal groups. In any case the result is the same: places attacked by FARC exhibit lower levels of turnout, while paramilitary actions have no clear effect. For the rationale behing each measure, see the Online Appendix.

\subsection{Causal Effect of Attacks on Turnout}

As discussed above, reverse causality might lead to biased estimates of the effects of civil conflict on voter turnout. For instance, if FARC forms an (precise) expectation of which municipalities will have a high level of turnout, and attack those places in order to suppress voters, a form of reverse causality would generate a downward bias of the estimates reported in table 1. Such a strategy makes sense if one of the objectives of this group is to sabotage elections and challenge the status quo. Conversely, if their strategy is to attack municipalities with low levels of turnout, because in these places the state's presence is weak or nonexistent, therefore making it is easier to attack, then the estimates will have an upward bias. To address these potential endogeneity issues, an instrumental variable approach is used as discussed in the empirical strategy section. Table 2 reports the causal effects of FARC and paramilitary violence on voter turnout, using two-stage least squares (2SLS) estimations.

In column 1 of table 2, the second stage results (equation (2)) are reported. Once more, the rate of FARC attacks per 100,000 habitants has a negative and significant effect on voter turnout. Importantly, the magnitude of the estimated parameter is larger (in absolute value) than any of the coefficients reported in table 1 . This finding suggests that without instrumenting the endogenous regressors, the OLS estimates are downwardly biased. Therefore, these results suggest that FARC attacks municipalities in which political participation is expected to be high, which is consistent with the idea that violence is used strategically to alter electoral outcomes or, simply, to sabotage the electoral process. In this case, the estimations 
suggest that a unit increase in the rate of attacks per 100,000 habitants reduces turnout by about 3.2 percentage points. This is certainly a non-negligible effect, given that if for municipalities with a non-zero rate of attacks the average rate is 7.01 , turnout is about 22 percentage points lower for an average municipality attacked by FARC when compared to a municipality not attacked. The effect is robust and even higher after municipality time-varying covariates are controlled. In such a case, the estimated coefficient is about -3.7 , suggesting that the predicted difference in turnout between a non-attacked municipality and one with the average rate among attacked municipalities is approximately 26 percentage points.

Column 1 in table 2 shows, for the first time, that paramilitary attacks have a positive and significant influence on turnout. However, significance disappears once time-varying controls are included as reported in column 4 . Once more, this result demonstrates consistency with the concept that paramilitary violence has a non-negative effect on turnout, as these groups formed alliances with politicians and, in many cases, coerced citizens to participate and support their candidates.

Finally, columns 2, 3, 5 and 6 in table 2 present the first stage results. In both cases, the interaction between the $(\log )$ distance to Caguan and the post 1998 dummy variable has a negative and significant effect on the rate of FARC attacks. This is consistent with the idea that in 2001 and 2005, after the Caguan process was over and President Uribe launched his anti-insurgency strategy against the guerrillas, violence close to and around the former demilitarized zone became more intense. This is not surprising given that during the peace process FARC increased its control over regions around Caguan, intensifying the production of illegal crops (coca) in these places. Therefore, after the peace process is over and given that the State army went after the insurgents in these regions, the increase in unilateral attacks reveals FARC's attempt to defend and preserve control over the area.

In addition, the interaction between the palm condition dummy and the post 1998 indicator variable has a negative and significant coefficient in both cases (with and without controls). This result suggests that, in 2001 and 2005, after the paramilitaries consolidated their expansion, the rate of unilateral attacks in municipalities suitable for the cultivation of palm tree was lower. This is consistent with the hypothesis that, if the paramilitaries gained control of these lands between 1997 and 2001, they were not interested in perpetrating attacks that could alter the exploitation of these lands. ${ }^{8}$

Given that there are two endogenous regressors (FARC and paramilitary attacks), Angrist and Pischke's F statistic is a suitable test for weak identification (Angrist and Pischke (2009)). Statistics reported in the table reveal that using these criteria for the two instruments, it is possible to reject the null hypothesis that the rates of FARC and paramilitary attacks are 
weakly identified. Consequently, the first stage results suggest that the excluded instruments are not weakly correlated with the endogenous regressors.

\subsection{Electoral Competition and Parties' Vote Shares}

If the paramilitaries have no effect on voter turnout, which variable is affected by their presence? Acemoglu, Robinson, and Santos (2009) show that in regions affected by paramilitary violence, after these actors got involved in politics, the change in third (non-traditional) parties' vote share was higher than in regions without paramilitary presence. ${ }^{9}$ Their argument is that para-politicians used this type of party, instead of traditional parties, in order to win elections. Here an alternative approach is employed. As it was previously argued, increasing turnout is not necessary for a candidate to win. But, if the paramilitaries are supporting certain candidates in their regions, after 1998, these places should exhibit different patterns in terms of electoral competition. The maximum vote share in each municipality is utilized as a measure of competition. ${ }^{10}$

Table 3 presents the basic results of this analysis, where only years 1998, 2002, and 2006 are studied. ${ }^{11}$ Columns $1-4$ use the maximum vote share as the dependent variable. It is clear that, on average, neither FARC nor paramilitary attacks have a significant effect on this variable. However, in specifications 3 and 4, FARC and paramilitaries' rates of attacks interact with year dummies for the purpose of identifying if there are any differential effects across time. The results are quite revealing. Compared to 1998, in 2002 and 2006 (after the paramilitaries became involved in politics), the maximum vote share tended to be higher as paramilitary attacks increased. These findings suggests that, in regions with paramilitary presence, after they became involved in politics, electoral competition was lower. Naturally, this result supports the idea that these self-defense right-wing groups were intentionally altering electoral outcomes. The results do not hold in the case of FARC violence. Also, Columns 5 and 6 show that this pattern does not hold for voter turnout, suggesting that if a determination of how the paramilitaries affected elections is desired, it is necessary to look at other types of variables. It is important to note that given the degree of control that the paramilitaries

had in "their" regions, it was difficult or impossible for the opposition (left-wing, and in some cases, traditional) parties to counteract their strategies. ${ }^{12}$

Naturally, if the paramilitaries were affecting electoral competition, with the maximum vote share obtained by a candidate increasing after 1998, there should be winners and losers from this process. As in Acemoglu, Robinson, and Santos (2009), table 4 shows that third parties exhibit an increase in their vote share after the paramilitaries became involved in politics. Columns 3 and 4 illustrate that the interactions between paramilitary attacks and the 
time dummies for 2002 and 2006 are positive and statistically significant. ${ }^{13}$ Column 3 shows estimations without controls, which are included in column 4 . These results suggest that there is a differential growth effect for these years as compared to 1998. The coefficients of 0.258 and 0.337 reported in column 4 reveal, for instance, that holding everything else constant, if a municipality has the average rate of an attacked municipality (instead of having a rate of zero paramilitary attacks), third parties' vote share is about 3 percentage points higher in 2002 and about 4 points higher in 2006. ${ }^{14}$ Therefore, empirically these findings support the premise that in 2002 and 2006, after the paramilitaries became involved in politics, third parties were the channel used by these groups to alter electoral outcomes.

Columns 3 and 4 show that FARC violence does not have an equivalent impact on third parties' vote share. This result suggests that the decrease in turnout caused by FARC presence has an equivalent effect on all political parties and that this group is not strategically reducing turnout on a selective basis.

In columns 7 and 8, it is shown that traditional parties (Liberal and Conservative parties) are the main losers of this process. The negative and significant coefficients associated with the interactions of the paramilitary rates of attacks and the time dummies reveal that the vote shares of these parties exhibited a differential decrease as compared to 1998. Again, these findings are consistent with the idea that the paramilitary influence was not channeled through the Liberal or Conservative parties. Also, these columns reveal that the FARC attacks have no differential effect across time on the vote share of these parties. Finally, table 5 shows that these effects are mainly a consequence of a differential reduction in the Liberal party's vote share. Columns 3 and 4 show that, in 2002 and 2006, there is a reduction in this party's vote share, whereas columns 7 and 8 show that there is no significant effect of paramilitary attacks on the Conservative party's share. This result is consistent with the fact that many Liberal politicians, after 1998, left this party to join or create new organizations. ${ }^{15}$ Table A.4 in the Online Appendix illustrates that all the results of the effects of paramilitary violence on parties' vote shares are robust to an alternative measure of conflict, a dummy variable indicating if municipality $i$ had any form of (FARC or paramilitary) attack on a given year.

Overall, the results presented here support the idea that FARC's strategy is to suppress turnout, while the paramilitaries affect electoral outcomes (in favor of third parties and against traditional parties, especially the Liberal Party) and electoral competition (with higher maximum vote shares in paramilitary regions). Additionally, FARC violence is higher during an election year, while the paramilitaries are more violent on non-election years. 


\subsection{Testing the Mechanism}

In this paper, it is stressed that military conditions of illegal groups exert some influence on the methods available to alter electoral results. In the case of guerrilla groups fighting an irregular (asymmetric) war (Kalyvas and Balcells, 2010), guerrilla warfare implies taking advantage of mobility and terrain roughness. This situation is the case of FARC in Colombia, especially after 2002 when president Uribe launched his anti-insurgency campaign. In such a scenario, it is much harder for an irregular group to achieve control of the population, to establish strong ties and to cooperate with civilians, especially with rural elites. When control is achieved, it generally takes place in peripheral areas. Therefore, creating alliances with candidates, which implies medium and long run investments, becomes hard or unfeasible. In the case of paramilitaries, the situation is quite different. These groups emerged as a counter-insurgent reaction and were sponsored by ranchers, landowners, entrepreneurs, and narco-traffickers. Hence, in the absence of a strong state, territorial stability in populated and non-peripheral regions was a key characteristic that allowed AUC to provide security to the sponsoring elites. In such circumstances, control of the population is easier and fundamental, which includes coercing civilians to vote for the candidates of their alliances.

Consequently, the mechanism proposed in this paper has two components. First, the impact of violence on voting outcomes is the result of deliberate strategies followed by illegal armed groups to alter the elections. And second, these strategies respond to military and structural conditions that characterize the groups and their interaction with civilians. To support this mechanism, this paper proceeds in two stages. First, to support the idea that strategies are deliberate, each group's rate of attacks on electoral years versus non-electoral years is analyzed. Second, to show that military conditions matter, the fact that FARC's situation has changed over time is exploited. In particular, focus includes the finding that, after 2002, with the strengthening of the Colombian state, this guerrilla group lost control of many regions and had to rely more on typical guerrilla warfare.

Table 6 reports the main results of OLS regressions where FARC or paramilitary attacks are the outcomes, as a function of dummies indicating election years and municipality-level controls and fixed effects. Columns 1 and 3 suggest that, during electoral years, the rate of FARC attacks is significantly higher. For the rate of paramilitary attacks, the result is the opposite. Hence, these results support the mechanism proposed above to explain the divergent effect of FARC versus paramilitary violence on voting behavior.

Finally, Table 7 shows that the effect of FARC violence on turnout varies over time as suggested by the proposed mechanism. Columns differ in terms of the conflict measured employed. In every specification, the coefficient of the interaction between FARC attacks and 
a post 2002 dummy is negative and significant. These findings shows that, after 2002, FARC attacks have an increased (negative) impact on turnout, supporting the hypothesis that the strengthening of the Colombian state and the retreat of FARC in many regions made them more reliant on sabotage and suppression as strategies for altering elections.

Summing up, the results of this section support the hypothesis that attacks of two different illegal organizations have different effects on voting outcomes as a consequence of divergent deliberate strategies used by these groups. In turn, such strategies result from military conditions that differentiate FARC from paramilitaries. ${ }^{16}$

\section{Conclusion}

A clear understanding of how illegal groups alter democracy is fundamental, given the wave of democratization that took place in the last decades around the world. This paper shows that in a context in which civil war and elections coexist, illegal armed groups use divergent strategies for the purpose of altering electoral outcomes. The results produced suggest that FARC's violence heavily affected voter turnout, with citizens living in regions affected by this group voting less. Paramilitaries, on the contrary, altered electoral competition after 1998, with lower levels of competition in municipalities affected by right-wing violence and with newly created third-parties having better results in these regions.

Naturally, the main challenge posed by these findings is explaining why different illegal armed groups use different strategies to alter electoral outcomes. Here, one possible explanation is proposed: the relation between illegal groups and the local dominant elites determines the behavior of these organizations. The dynamics of war support this explanation. Structural conditions that define Colombia's conflict might explain these patterns. Guerrilla groups, like FARC, tend to be mobile and generally do not stay in the same place for long periods of time. Consequently, it is hard for these groups to offer security to the (legal or illegal) economic elites that control a region. The paramilitaries, on the contrary, are more stable and use to stay in the same place for longer periods. Therefore, in the presence of a weak State, these groups are successful at offering private security to local elites. This argument would explain, in part, why the paramilitaries capture the State from inside, through alliances with politicians, while FARC is unable to make these alliances and prefers to sabotage the electoral process. This statement does not pretend to suggest that ideology plays no role. It is just the recognition that material conditions might determine how these violent organizations operate.

Even though the Colombian case is interesting and dramatic, studies like Wilkinson (2006) and Collier and Vicente (2014) reveal that in many other contexts there is a clear relation between conflict and political behavior. Why is it the case that different groups use different 
strategies to alter electoral results? Is it always the case that right-wing armed groups form alliances with incumbents and elites in order to perpetuate the status quo? Is it always the case that insurgent groups attack democratic institutions suppressing turnout? Naturally, for understanding the patterns found here, and in order to answer these questions and challenges, we need a general theory of how illegal armed groups affect electoral outcomes in a context of civil war. That should be the next step. 


\section{Notes}

${ }^{1}$ Senate elections are analyzed in this paper to show the magnitude of the problem, as illegal groups were able to shape the composition of national level entities like the Congress. When presidential or local elections are analyzed, similar results arise, especially in terms of turnout.

${ }^{2}$ Naturally, this argument is false if armed groups have the capacity of anticipating, some months in advance, how many people will turnout or how they will vote in certain municipalities.

${ }^{3}$ In other specifications, not reported here, other controls such as displacement, are utilized. The results are robust to these alternative specifications

${ }^{4}$ These interactions are included in order to avoid potential endogeneity between the time-varying versions of these variables and the measures of conflict. For this to be true, it is important to note that I use, when possible, measures of these variables previous to 1994.

${ }^{5}$ This argument would explain why the effect of paramilitary violence on voter turnout is not unambiguously positive.

${ }^{6}$ The natural $\log$ of distance is used in order achieve a better fit, given the dispersion of this variable, although other specifications were used as well (results not reported). See Gelman and Hill (2007).

${ }^{7}$ See some of the results below in order to determine the effects of paramilitary violence on political behavior.

${ }^{8}$ First stage results generate certain concerns at this point, in particular because the guerrilla instrument (distance to caguan interacted with the post 1998 dummy) has a significant effect on paramilitary violence. This relationship could bias the estimations. However, after including the municipality level controls, the paramilitary instrument does not have a significant effect on FARC attacks.

${ }^{9}$ Colombia had a long tradition of bipartisanship, in which the Liberal and Conservative parties have historically won most elections. However, by the end of the twentieth century this system experienced a drastic transformation, after a set new and non-traditional third parties emerged and consolidated.

${ }^{10}$ In general, the paramilitaries established alliances with one or few senatorial candidates per region, so that it makes more sense to explore the maximum vote share obtained by a candidate as a measure of political competition, versus other measures (such as the effective number of candidates or the Herfindahl-Hirshmann index of electoral concentration).

${ }^{11}$ Data is not available for 1994 .

${ }^{12}$ Mobilization efforts were unfeasible for those that opposed to the paramilitaries, because violence was a very effective strategy for these illegal armed groups. Many candidates, both for local and national elections, were killed during this period.

${ }^{13}$ The coefficient associated with the rate of paramilitary attacks and the 2002 time dummy in column 3 is barely insignificant at a $10 \%$ confidence level. However, it becomes significant once we include the time-varying controls (column 4).

${ }^{14}$ Results reported in table A.4 allow an easier interpretation of these effects.

${ }^{15}$ In fact, right-wing President Uribe used to be a liberal candidate, but in 2002 and 2006 won through third-parties coalitions. The Liberal party was a member of the opposition to Uribe's administration.

${ }^{16}$ It could be argued that these results are conditional on the time period chosen for the analysis and that in other periods groups behaved in a different way. For instance, Steele (2011) shows how during the 1990's the paramilitaries sabotaged elections using a cruel strategy: displacing potential voters of left-wing parties in Apartado, Colombia. This evidence supports the main hypothesis presented in this paper: precisely when paramilitaries had no territorial control, as they were fighting for it, they relied on turnout suppression to alter electoral results. Similarly, it could be argued that at times and in certain places, FARC made alliances with certain candidates and coerced voters to support them. Again, this goes in line with the arguments of this 
paper, as such strategies were employed by FARC whenever they achieved territorial control in a region. 


\section{Bibliography}

Acemoglu, Daron, James Robinson, and Rafael Santos. "The Monopoly of Violence: Evidence From Colombia." Journal of the European Economic Association 11: (2013) 5-44.

Angrist, Joshua, and Jorn-Steffen Pischke. Mostly Harmless Econometrics. Princeton University Press, 2009.

Bekoe, Dorina. Voting in Fear: Electoral Violence in Sub-Saharan Africa. United States Institute of Peace Press, 2012.

Bellows, John, and Edward Miguel. "War and Local Collective Action in Sierra Leone." Journal of Public Economics 93: (2009) 1144-1157.

Berrebi, Claude, and Esteban Klor. "Are Voters Sensitive to Terrorism?: Direct Evidence from the Israeli Electorate." American Political Science Review 102: (2008) 279-301.

Blattman, Christopher. "From Violence to Conflict: War and Political Participation in Uganda." American Political Science Review 103: (2009) 231-247.

Brass, Paul. The Production of Hindu-Muslim Violence in Contemporary India. University of Washington Press, 2003.

Collier, Paul, and Pedro Vicente. "Votes and Violence: Experimental Evidence from a Nigerian Election." Economic Journal 124, 574: (2014) F327-F355.

Dube, Oeindrila, and Suresh Naidu. "Bases, Bullets and Ballots: the Effect of U.S. Military Aid on Political Conflict in Colombia." Journal of Politics 77, 1: (2015) 249-267.

Dunning, T. "Fighting and Voting: Violent Conflict and Electoral Politics." Journal of Conflict Resolution 55, 3: (2011) 327-339.

Garcia, Miguel. "Coercing Voters: Violent Contexts and Political Behavior in Colombia." Americas Barometer Small Grants Research Papers .

Gelman, Andrew, and Jennifer Hill. Data Analysis using Regression and Multilevel Hierarchical Models. Cambridge University Press, 2007.

Getmansky, A., and T. Zeitzoff. "Terrorism and Voting: The Effect of Rocket Threat on Voting in Israeli Elections." American Political Science Review 108, 3: (2014) 588-604.

Hefner-Burton, Emilie, and Ryan Jablonski. "When Do Governments Resort to Election Violence." British Journal of Political Science 44, 1: (2014) 149-179. 
Hoskin, Gary, and Miguel Garcia. Colombia 2002: Elecciones, comportamiento electoral, y democracia. Uniandes, 2003.

Kalyvas, Stathis. The Logic of Violence in Civial War. Cambridge University Press, 2006.

Kalyvas, Stathis, and Laia Balcells. "International System and Technologies of Rebellion: How the End of the Cold War Shaped Internal Conflict." American Political Science Review 104: (2010) 415-424.

Kibris, Arzu. "Funerals and Elections: the Effects of Terrorism on Voting Behavior in Turkey." Journal of Conflict Resolution 55: (2011) 220-247.

Lopez, Claudia. "La Ruta de la Expansion Paramilitar y la Transformacion Politica de Antioquia." in Romero (2007), 2007.

- Y refundaron la patria: De como mafiosos y politicos reconfiguraron el Estado colombiano. Editorial Debate, 2010.

Mingorance, Fidel, Flaminia Minelli, and Helene Le Du. El cultivo de la palma africana en el Choco. Human Rights Everywhere, 2004.

Montalvo, Jose. "Voting after the Bombings: A Natural Experiment on the Effect of Terrorist Attacks on Democratic Elections." Review of Economics and Statistics 93, 4: (2010) 11461154 .

Norton, Augustus. Hezbollah: a Short History. Princeton University Press, 2007.

Romero, Mauricio. Para Politica: La Ruta de la Expansion Militar y los Acuerdos Politicos. Corporacion Nuevo Arcoiris, 2007.

Snyder, Jack. From Voting to Violence. Democratization and Nationalist Violence. Norton, 2000 .

Varshney, Ashutosh. Ethnic Conflict and Civil Life: Hindus and Muslims in India. Yale University Press, 2002.

Weintraub, Michael, Juan Vargas, and Thomas Flores. "Vote Choice and Legacies of Violence: Evidence from the 2014 Colombian Presidential Elections." Research and Politics .

Wilkinson, Steven. Votes and Violence: Electoral Competition and Ethnic Riots in India. Cambridge University Press, 2006. 


\section{Tables}

Table 1: Effect of Attacks on Turnout

\begin{tabular}{|c|c|c|c|c|}
\hline & $(1)$ & $(2)$ & $(3)$ & $(4)$ \\
\hline & OLS FE & OLS FE & OLS FE & OLS FE \\
\hline Variable & Turnout & Turnout & Turnout & Turnout \\
\hline \multirow[t]{2}{*}{ Farc Attacks } & $-0.157^{* * *}$ & $-0.147^{* * *}$ & $-0.131^{* *}$ & $-0.123^{* *}$ \\
\hline & $(0.0492)$ & $(0.0508)$ & $(0.0517)$ & $(0.0523)$ \\
\hline \multirow[t]{2}{*}{ Paras Attacks } & -0.0225 & -0.0150 & -0.0143 & -0.0109 \\
\hline & $(0.0198)$ & $(0.0214)$ & $(0.0164)$ & $(0.0174)$ \\
\hline \multirow[t]{2}{*}{ State Attacks } & -0.0164 & -0.0343 & -0.0206 & -0.0296 \\
\hline & $(0.0200)$ & $(0.0239)$ & $(0.0187)$ & $(0.0210)$ \\
\hline \multirow[t]{2}{*}{ Lagged Farc } & & $-0.105^{* *}$ & & $-0.102^{* *}$ \\
\hline & & $(0.0492)$ & & $(0.0441)$ \\
\hline \multirow[t]{2}{*}{ Lagged Paras } & & -0.0364 & & -0.0107 \\
\hline & & $(0.0699)$ & & $(0.0645)$ \\
\hline \multirow[t]{2}{*}{ Lagged State } & & $0.0587 * * *$ & & $0.0390 *$ \\
\hline & & $(0.0226)$ & & $(0.0208)$ \\
\hline \multirow[t]{2}{*}{ Constant } & $36.49^{* * *}$ & $36.57^{* * *}$ & $35.77^{* * *}$ & $35.85^{* * *}$ \\
\hline & $(0.313)$ & $(0.313)$ & $(0.251)$ & $(0.249)$ \\
\hline Time-Varying Controls & $\mathrm{N}$ & $\mathrm{N}$ & $\mathrm{Y}$ & $\mathrm{Y}$ \\
\hline Observations & 3,928 & 3,928 & 3,824 & 3,824 \\
\hline R-squared & 0.153 & 0.156 & 0.265 & 0.268 \\
\hline Number of mun. & 989 & 989 & 957 & 957 \\
\hline
\end{tabular}

Robust standard errors in parentheses

$$
\text { *** } \mathrm{p}<0.01,{ }^{* *} \mathrm{p}<0.05,{ }^{*} \mathrm{p}<0.1
$$




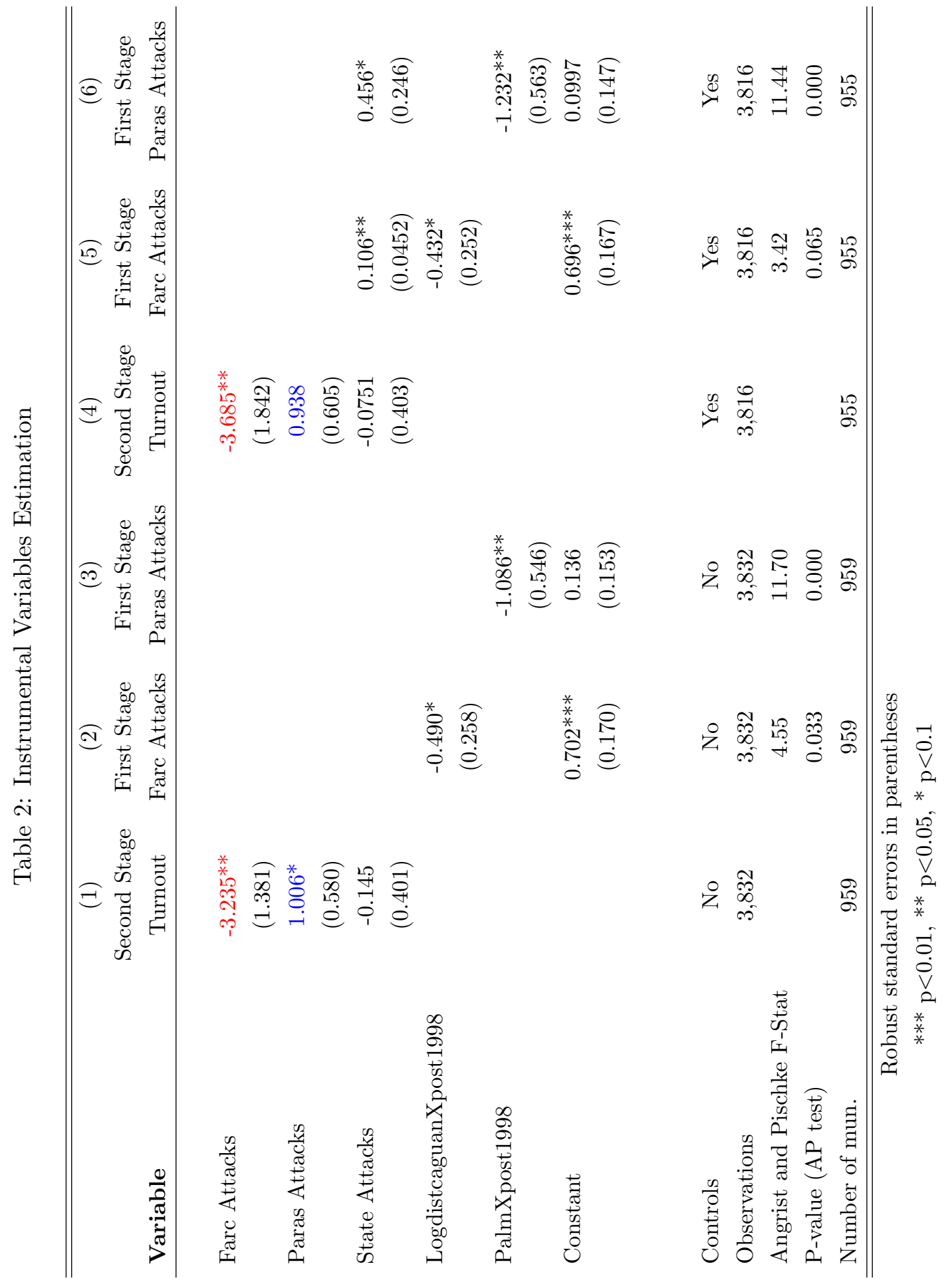




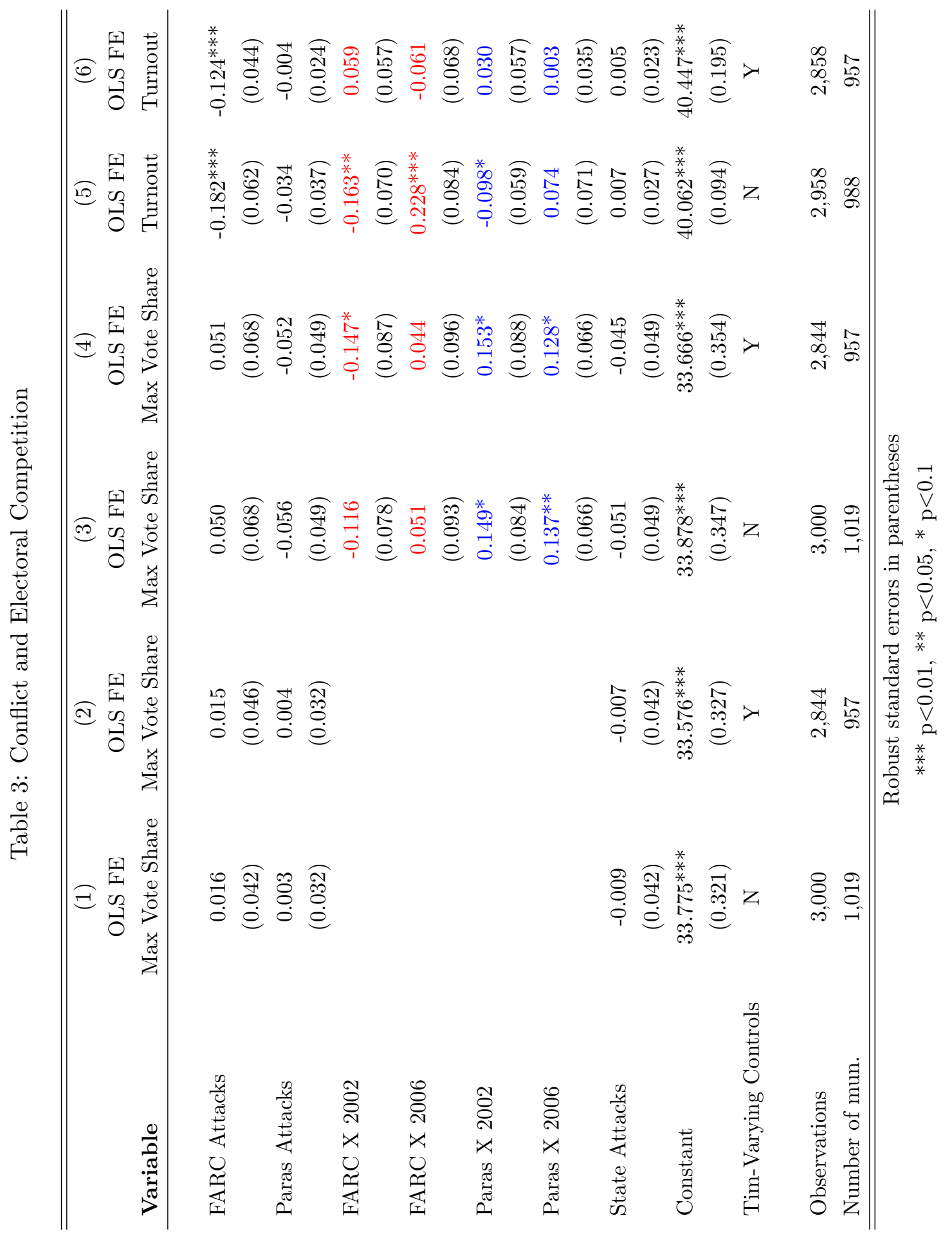




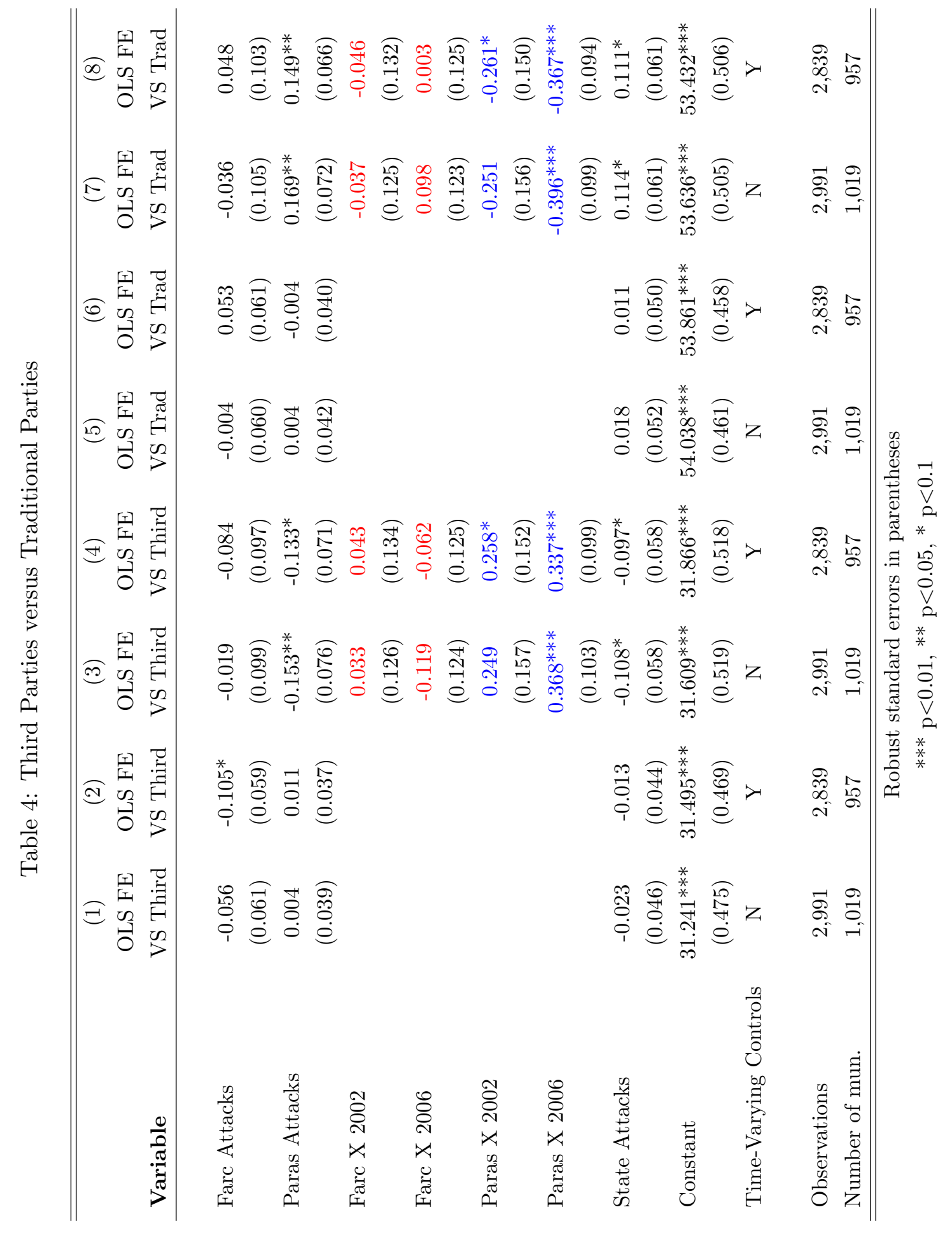




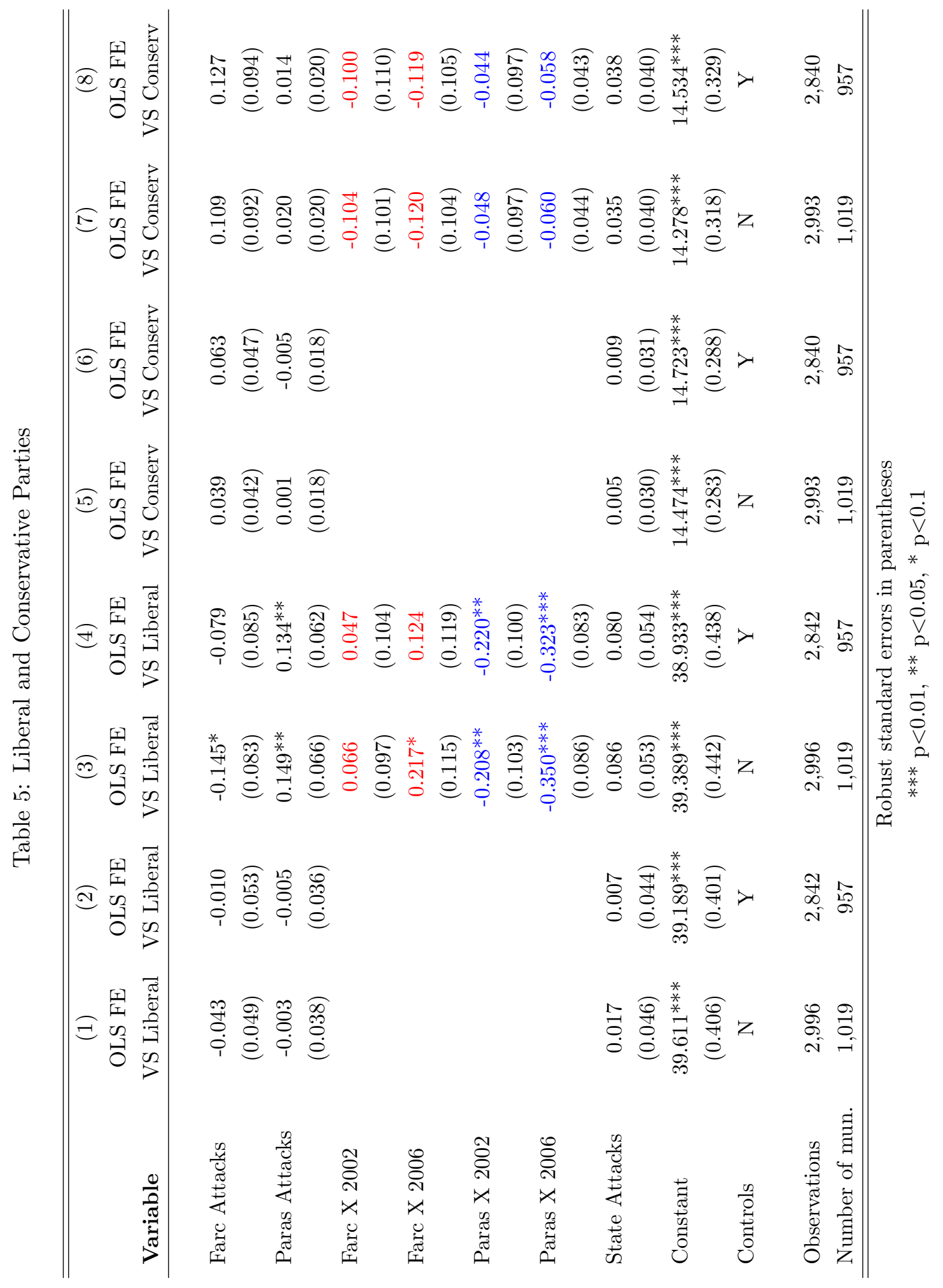


Table 6: Attacks During Election Years

\begin{tabular}{lcccc}
\hline \hline & $(1)$ & $(2)$ & $(3)$ & $(4)$ \\
Variable & OLS FE & OLS FE & OLS FE & OLS FE \\
& Farc Attacks & Paras Attacks & Farc Attacks & Paras Attacks \\
\hline \multirow{2}{*}{ Electionyear } & $0.0749^{* * *}$ & $-0.0578^{* * *}$ & $0.0748^{* * *}$ & $-0.0602^{* * *}$ \\
& $(0.0115)$ & $(0.0106)$ & $(0.0116)$ & $(0.0109)$ \\
Logpopulation & $1.151^{* * *}$ & $0.852^{* * *}$ & $1.155^{* * *}$ & $0.919^{* * *}$ \\
& $(0.132)$ & $(0.155)$ & $(0.134)$ & $(0.158)$ \\
Popdensity & $-3.07 \mathrm{e}-05$ & 0.000743 & $-3.08 \mathrm{e}-05$ & 0.000741 \\
Elecyearmun & $(0.000155)$ & $(0.000557)$ & $(0.000155)$ & $(0.000558)$ \\
Constant & & & 0.00372 & $0.0668^{* * *}$ \\
& $-10.87^{* * *}$ & $-8.147^{* * *}$ & $-10.91 * * *$ & $-8.820^{* * *}$ \\
& $(1.269)$ & $(1.462)$ & $(1.289)$ & $(1.497)$ \\
Observations & 22,021 & 22,021 & 22,021 & 22,021 \\
Number of mun. & 1,019 & 1,019 & 1,019 & 1,019 \\
\hline \hline
\end{tabular}

Robust standard errors in parentheses

*** $\mathrm{p}<0.01, * * \mathrm{p}<0.05, * \mathrm{p}<0.1$ 
Table 7: Effect of Conflict on Turnout after 2002

\begin{tabular}{|c|c|c|c|c|c|c|}
\hline \multirow[b]{3}{*}{ Variable } & (1) & $(2)$ & (3) & (4) & (5) & (6) \\
\hline & OLS FE & OLS FE & OLS FE & OLS FE & OLS FE & OLS FE \\
\hline & Turnout & Turnout & Turnout & Turnout & Turnout & Turnout \\
\hline \multirow[t]{2}{*}{ FARC Attacks } & $-0.108^{* *}$ & -0.0761 & & & & \\
\hline & $(0.0514)$ & $(0.0523)$ & & & & \\
\hline \multirow[t]{2}{*}{ Paras Attacks } & $-0.0543^{*}$ & $-0.0440^{*}$ & & & & \\
\hline & $(0.0297)$ & $(0.0241)$ & & & & \\
\hline \multirow[t]{2}{*}{ State Attacks } & $-0.0956^{*}$ & -0.0740 & & & & \\
\hline & $(0.0553)$ & $(0.0534)$ & & & & \\
\hline \multirow{2}{*}{ FARCAttacks X Post2002 } & $-0.192^{* *}$ & $-0.227^{* * *}$ & & & & \\
\hline & $(0.0800)$ & $(0.0784)$ & & & & \\
\hline \multirow[t]{2}{*}{ ParasAttacks X Post2002 } & 0.0679 & 0.0582 & & & & \\
\hline & $(0.0469)$ & $(0.0433)$ & & & & \\
\hline \multirow[t]{2}{*}{ StateAttacks X Post2002 } & 0.101 & 0.0765 & & & & \\
\hline & $(0.0642)$ & $(0.0611)$ & & & & \\
\hline \multirow[t]{2}{*}{ Average FARC Attacks } & & & $-0.237^{* * *}$ & $-0.175^{* *}$ & & \\
\hline & & & $(0.0745)$ & $(0.0758)$ & & \\
\hline \multirow[t]{2}{*}{ Average Paras Attacks } & & & $-0.125^{*}$ & $-0.106^{*}$ & & \\
\hline & & & $(0.0676)$ & $(0.0564)$ & & \\
\hline \multirow[t]{2}{*}{ Average State Attacks } & & & -0.201 & -0.130 & & \\
\hline & & & $(0.165)$ & $(0.154)$ & & \\
\hline \multirow[t]{2}{*}{ AverageFARC X Post2002 } & & & $-0.188^{*}$ & $-0.254^{* *}$ & & \\
\hline & & & $(0.110)$ & $(0.106)$ & & \\
\hline \multirow[t]{2}{*}{ AverageParas X Post2002 } & & & 0.143 & 0.150 & & \\
\hline & & & $(0.121)$ & $(0.117)$ & & \\
\hline \multirow[t]{2}{*}{ AverageState X Post2002 } & & & $0.327^{*}$ & 0.228 & & \\
\hline & & & $(0.168)$ & $(0.158)$ & & \\
\hline \multirow[t]{2}{*}{ FARC Presence } & & & & & $-1.972^{* * *}$ & $-1.455^{* * *}$ \\
\hline & & & & & $(0.574)$ & $(0.514)$ \\
\hline \multirow[t]{2}{*}{ Paras Presence } & & & & & $-1.105^{*}$ & $-1.337^{* *}$ \\
\hline & & & & & $(0.628)$ & $(0.562)$ \\
\hline \multirow[t]{2}{*}{ State Presence } & & & & & -0.631 & -0.735 \\
\hline & & & & & $(0.563)$ & $(0.494)$ \\
\hline \multirow[t]{2}{*}{ FARCPresence X Post2002 } & & & & & $-2.982^{* * *}$ & $-3.016 * * *$ \\
\hline & & & & & $(0.913)$ & $(0.924)$ \\
\hline \multirow[t]{2}{*}{ ParasPresence X Post2002 } & & & & & 0.572 & $2.109^{* *}$ \\
\hline & & & & & $(1.059)$ & $(1.026)$ \\
\hline \multirow[t]{2}{*}{ StatePresence X Post2002 } & & & & & 0.722 & $1.461^{*}$ \\
\hline & & & & & $(0.887)$ & $(0.849)$ \\
\hline \multirow[t]{2}{*}{ Constant } & $36.47^{* * *}$ & $35.74^{* * *}$ & $36.67^{* * *}$ & $35.89^{* * *}$ & $38.12^{* * *}$ & $36.19^{* * *}$ \\
\hline & $(0.312)$ & $(0.250)$ & $(0.316)$ & $(0.251)$ & $(0.413)$ & $(0.287)$ \\
\hline Controls & $\mathrm{N}$ & $\mathrm{Y}$ & $\mathrm{N}$ & $\mathrm{Y}$ & $\mathrm{N}$ & $\mathrm{Y}$ \\
\hline Observations & 3,928 & 3,824 & 3,928 & 3,824 & 3,948 & 3,824 \\
\hline Number of Mun. & 989 & 957 & 989 & 957 & 989 & 957 \\
\hline
\end{tabular}

